\title{
A New foodweb based on microbes in calcitic caves: The Cansiliella (Beetles) case in Northern Italy
}

\author{
Maurizio G. Paolettia ${ }^{*}$ Mattia Beggio ${ }^{\mathrm{a}}$, Angelo Leandro Dreon ${ }^{\mathrm{a}}$, Alberto Pamio ${ }^{\mathrm{a}}$, Tiziano Gomiero ${ }^{\mathrm{a}}$, \\ Mauro Brilli ${ }^{\mathrm{b}}$, Luca Dorigo ${ }^{\mathrm{e}}$, Giuseppe Concheric ${ }^{\mathrm{c}}$, Andrea Squartini ${ }^{\mathrm{c}}$, Annette Summers Engel ${ }^{\mathrm{d}^{*}}$
}

\begin{abstract}
:
Paoletti M.G., Beggio M., Dreon A.L., Pamio A., Gomiero T., Brilli M., Dorigo L., Concheri G., Squartini A., Summers Engel A. 2011. A new foodweb based on microbes in calcitic caves: the Cansiliella (Beetles) case in Northern Italy. International Journal of Speleology, 40(1), 45-52. Tampa, FL (USA). ISSN 0392-6672. DOI: 10.5038/1827-806X.40.1.6

The troglobitic beetle, Cansiliella servadeii (Leptodirini), has specialized mouthparts modified for browsing and feeding under percolating water on moonmilk, a speleothem formation in Grotta della Foos, Italy. Results from analyses of stable isotopes of carbon and nitrogen suggest that acquires and assimilates dissolved allochthonous organic carbon, inorganic nitrogen, and possibly phosphorus and other nutrients from the microbial fauna associated with moonmilk.
\end{abstract}

Keywords: Cansiliella servadeii, cave, moonmilk, stable isotopes, food web, bacteria, microorganisms

Received 3 September 2010; Revised 6 December 2010; Accepted 16 December 2010

\section{INTRODUCTION}

In air-filled cave and karst habitats, troglobites and troglophiles rely on an influx of allochthonous (surface-derived) organic matter from dripwaters or sheetflow on moist cave-wall surfaces. This habitat type is referred to as the cave hygropetric (Sket, 2004). Hydrological isolation for some cave hygropetric habitats may restrict the influx of organic matter, making a habitat nutrient-limited overall. Consequently, food limitation over extended periods of time has served as a major driver for evolutionary adaptation for troglobites (e.g., Sket, 2004). One highly evolved, troglobitic beetle, Cansiliella servadeii Paoletti 1980 (Coleoptera: Leptodirini, formerly Bathysciinae), has been found at a depth of $\sim 450 \mathrm{~m}$ below the surface in Grotta della Foos, northeastern Italy.

\footnotetext{
a Dipartimento di Biologia, Università di Padova, Agroecology and Ethnobiology, 35100- Padova, Italy, paoletti@bio.unipd.it

${ }^{\mathrm{b}}$ Istituto di Geologia Ambientale e Geoingegneria, CNR, 00015 Monterotondo St. (Roma), Italy;

c Dipartimento di Biotecnologie Agrarie, Università di Padova, Viale dell'Università 16, 35020 Legnaro (Padova) Italy

${ }^{\mathrm{d}}$ Louisiana State University, Department of Geology and Geophysics, Baton Rouge, Louisiana 70803 USA

${ }^{e}$ Museo Friulano di Storia Naturale, Udine, Italy

* Corresponding Authors
}

The genus Cansiliella consists of the species C. servadeii, C. tonielloi Paoletti 1972, and C. montisceseni (Piva, 2000). Cansiliella, as well as other beetles from the genus Hadesia, and possibly the recently described genera Radziella, Velebitodromus, Croatodirus, Nauticella, Tartariella, and Kircheria, have peculiar, semi-aquatic feeding behavior morphological structures that differ greatly from the majority of other troglobitic Leptodirini (Jeannel, 1924; Remy, 1940; Paoletti, 1973;1980; Moldovan et al., 2004; Sket, 2004; Giachino \& Vailati, 2006; Perrau \& Pavicevic, 2008; Paoletti et al., 2009). The mouthparts of Cansiliella spp. are adapted for a semi-aquatic feeding behavior and show modified hoe-shaped mandibles and spoon-like galeae with fine, dense setae for filtering (e.g., Moldovan et al., 2004; Paoletti et al., 2009). The food sources for these beetles have not been thoroughly studied yet, although the beetles do not feed upon guano or cricket eggs, carrion, or particulate organic matter such as woody debris. They cannot be easily captured by guano, rotting meat, cheese, or other baits routinely used for troglobite collection in caves. Sket (2004) hypothesized that Cansiliella may have a microphagous feeding habit or filter fine particles of allochthonous organic material from water.

The $C$. servadeii beetles from Grotta della Foos are essentially found associated with moonmilk, a secondary carbonate speleothem, that forms from percolating waters containing little to no surfacederived organic matter (Figure 1) (Engel, unpublished results). Moonmilk is a hydrated, spongy to powdery assemblage of microcrystalline carbonate minerals, 


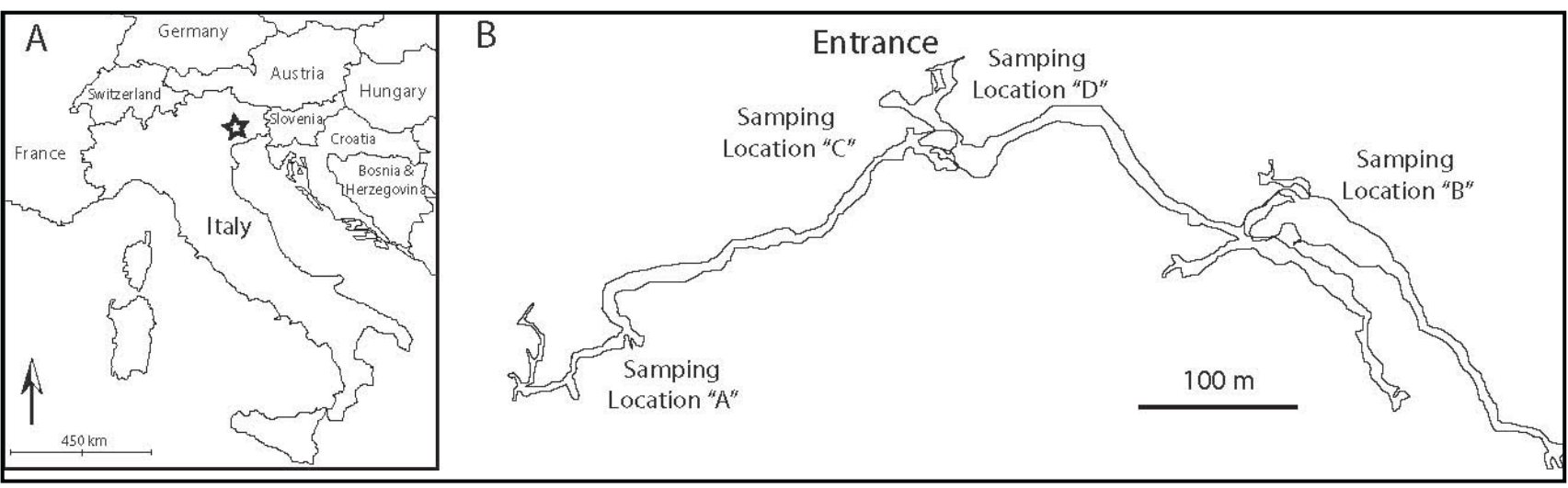

Fig. 1. (A) General location map for Grotta della Foos, Italy (star). (B) Plan view cave map modified from Gasparo (1971). Letters denote sampling locations. Exact locations are not revealed because the cave and beetle population are not protected. See text for details. Cansiliella servadeii, shown in Figure 2, were collected from Sampling Location "B".

resembling toothpaste or marzipan (Hill \& Forti, 1997). Moonmilk is usually rich in microbial biomass that may or may not be involved in moonmilk formation (e.g., Borsato et al., 2000; Northup et al., 2000; Northup \& Lavoie, 2001; Mulec et al., 2002; Van de Kamp et al., 2004; Cañaveras et al., 2006; Blyth \& Frisia, 2008), and the microbes are intermixed with carbonate minerals rather than form a separate, distinct biofilm on the surface (e.g., Borsato et al., 2000). We are currently characterizing the diversity of microbes and meiofauna from the moonmilk, of which we determined there was $\sim 10^{8}$ microbial cells $/ \mathrm{ml}$ and $\sim 10^{4}$ meiofauna cells $/ \mathrm{m}^{2}$ (Paoletti et al., 2009).

Based on the assumption that animal tissues reflect the assimilated isotopic composition of their food (Ponsard \& Arditi, 2000), we evaluated the food web position of $C$. servadeii and other cave animals with respect to the moonmilk and to the cave water using stable carbon and nitrogen isotope ratio analyses. Despite recent investigations that diverse microbial activities in non-sulfur based caves can support diverse food webs and trophic level interactions (e.g., Simon et al., 2003; Gerič et al., 2004; Opsahl \& Chanton, 2006), moonmilk microbial communities have not been previously considered a food source for invertebrates, especially troglobitic cave beetles. In the present study, we assess whether $C$. servadeii consumes organic matter, such as microbial cells, in moonmilk as its main food source. This work extends our current understanding of subsurface food webs (Gibert \& Deharveng, 2002) and may provide clues as to the unique evolutionary and morphological adaptations of $C$. servadeii and other troglobites in cave hygropetric habitats.

\section{MATERIALS AND METHODS}

\section{Sample collection and microscopy}

Grotta della Foos formed within Monte Ciaurlec which is underlain by Cretaceous and Triassic limestone units (Gasparo, 1971; Beggio, 2009). The cave contains over $2600 \mathrm{~m}$ of passages. Specific geologic details regarding the cave can be found in Gasparo (1971). Four sampling locations within the cave were chosen, although $C$. servadeii was collected only from location "Site B" (Figure 1). Basic sampling details are withheld because the $C$. servadeii population size is not yet known and the cave is not protected; the beetles are at risk of over-collection. Foraging and feeding behaviors of $C$. servadeii were documented using digital and video cameras. A video of $C$. servadeii from the cave can be viewed at http://geol.lsu.edu/aengel/ publications.htm and https://sites.google.com/site/ maurizioguidopaoletti/download-area/videos.

Other cave invertebrates were collected throughout the cave, including the saprofagous beetles Orostygia pretneri and Bryaxis persicoi, the carabid beetle Anophthalmus nivalis charon, the aquatic isopod Monolistra lavalensis, and the terrestrial isopod Androniscus noduliger (Figure 1). For comparison, samples of surface soil and invertebrates from the soil and forest litter near the cave entrance were collected, including five different isopod species (Protracheoniscus politus amoenus, Armadillidium vulgare, Trachelipus sp., Trichoniscus sp., and Ligidium germanicum). A few A. noduliger specimens were also acquired from small dolines at the top of Monte Cavallo at an altitude of 2000 m. All specimens were identified by M.G. Paoletti (unpublished data).

C. servadeii and $O$. pretneri individuals were analyzed with scanning electron microscopy (SEM). Samples were either air-dried or washed in alcohol and covered with a thin gold layer. A Philips XL30 ESEM ${ }^{\circledR}$ TMP environment (E-)SEM was used to observe non-dehydrated samples that were mounted on a thermoregulated holder. Experimental conditions were normally at $5^{\circ} \mathrm{C}$ at 4.5 to 6.5 Torr in the instrumental chamber. The ESEM was capable of X-ray fluorescence $(\mathrm{XRF})$, induced by the electron primary beam and detected in Energy Dispersive Spectroscopy (EDS) mode, to determine the elemental composition of moonmilk.

\section{Water analyses}

Basic geochemical analyses of percolating water samples were done, including $\mathrm{pH}$, temperature, and specific conductance using standard electrode methods. Water was filtered to $0.2 \mu \mathrm{m}$, and major anions and cations were measured by single column ion chromatography. The amount of dissolved organic carbon in cave water was determined by the dichromate oxydimetric method. Briefly, $50 \mathrm{ml}$ of water were supplemented with $1 \mathrm{ml}$ of $1 \mathrm{M} \mathrm{K}_{2} \mathrm{Cr}_{2} \mathrm{O}_{7}$

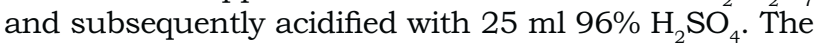
absorbance at $600 \mathrm{~nm}$ was read spectrophotometrically and compared against a standard curve obtained with increasing D-glucose concentrations. 


\section{Carbon and nitrogen stable isotope systematics}

Biological processes result in distinct isotopic values based on the differential utilization and isotopic discrimination (called fractionation). For the most part, metabolic discrimination between the lighter and heavier isotopes is predictable and can be used to track food sources among individuals within a community and estimate trophic level status. Comparisons of carbon (C) and nitrogen (N) isotope compositions are routine for terrestrial and aquatic food webs (e.g., DeNiro \& Epstein, 1981; Post, 2002; West et al., 2006). Given its typical adaptations, we did not assume that $C$. servadeii could leave the cave, and because we had not observed individuals in other parts of the cave, beetle $\mathrm{C}$ and $\mathrm{N}$ isotopic compositions were assumed to represent its local food source. However, we recognized that tracing an assimilated primary food source of a mobile animal is difficult because the isotopic values of an individual could be biased by its most recent feeding pattern and by tissue turnover rates for that individual (Post, 2002). As we know very little about the tissue turnover rates of $C$. servadeii and the other invertebrates, we used whole individuals and attempted to use only adults to minimize possible differences in body tissue composition. Moreover, because it was unclear whether or not the beetle guts were completely purged prior to isotopic analyses, we analyzed the dissected gut from Cansiliella specimens separately.
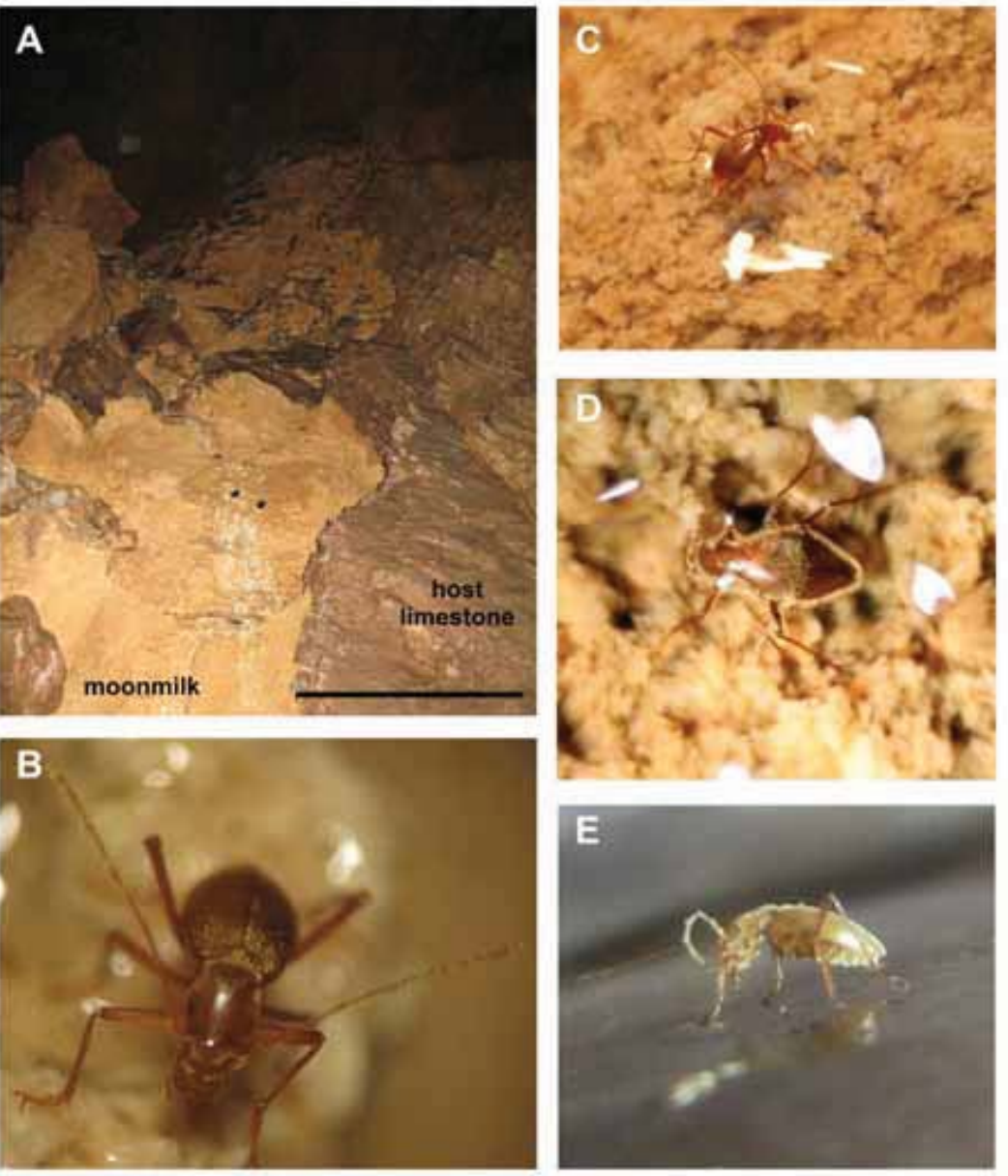

Fig. 2. (A) Cansiliella servadeii habitat on cave hygropetric moonmilk and host limestone, in Grotta della Foos, Italy. Scale bar approximately $1 \mathrm{~m}$. (B) Close-up of $C$. servadeii male (length of beetle is $2.8 \mathrm{~mm}$ ) on moonmilk. (C) C. servadeii moving on moonmilk with head and mouthparts under percolating water. (D) C. servadeii enclosed by air balloon inside water on moonmilk. (E) C.senvadeii preening activity.
The stable organic carbon (C) and nitrogen (N) isotopic composition of the invertebrates was done from the same sample, but the organic $\mathrm{C}$ and $\mathrm{N}$ isotope compositions from the soils and moonmilk were analyzed separately. Whole invertebrate specimens were dried, crushed, and weighed. Stable organic C isotope compositions from soil and moonmilk were done after removing inorganic carbonate with a solution of $1 \mathrm{~N} \mathrm{HCl}$ for 16 $\mathrm{hr}$ at room temperature while monitoring reaction $\mathrm{pH}$ (Midwood \& Boutton, 1997). Because the acidification procedure could result in the loss of $\mathrm{N}$-acid soluble organic matter and enhanced ingassing of $\mathrm{NH}_{3}$, the $\mathrm{N}$ isotope analysis of the soils and moonmilk were performed on non-acidified samples. Samples were rinsed to $\mathrm{pH} 5.5$ in $\mathrm{DI} \mathrm{H}_{2} \mathrm{O}$, dried at $50{ }^{\circ} \mathrm{C}$, and then ground to a fine powder.

An aliquot from each sample was flash combusted on an EA 1110 Carlo Erba elemental analyzer coupled on line to an isotope ratio mass spectrometer (IR-MS) Delta plus Finnigan MAT that was operated in the continuous flow mode using $\mathrm{He}$ as a carrier gas. Combustion was in an oxygen atmosphere in a quartz reactor packed with $\mathrm{Cr}_{2} \mathrm{O}_{3}$ and $\mathrm{Co}_{3} \mathrm{O}_{4} \mathrm{Ag}$ to form $\mathrm{CO}_{2}$, $\mathrm{N}_{2}$, NOx, and $\mathrm{H}_{2} \mathrm{O}$. The gases were passed through a copper furnace $\left(650^{\circ} \mathrm{C}\right)$ to reduce NOx to $\mathrm{N}_{2}$, and water was subsequently removed by $\mathrm{MgClO}_{4}$. Finally, $\mathrm{CO}_{2}$ and $\mathrm{N}_{2}$ were separated by gas chromatography (4 m, 1/ 4-inch Poraplot Q column) and introduced to the IR-MS via the Finnigan ConFlo II open split interface with reference gases inserted as pulses of pure standard gases. Isotope compositions are expressed in standard delta notation $(\delta$, units of $\%$ o) relative to known standards (Pee Dee Belemnite for $\mathrm{C}$ and AIR for N). Precision of individual isotope ratio measurements, as measured by internal laboratory organic standards, was $\pm 0.2 \%$ for $\delta^{13} \mathrm{C}$ and $\pm 0.1 \%$ o for $\delta^{15} \mathrm{~N}$ values. Isotope results were normalized using IAEA-CH6, IAEA-CH7, and USGS24 for C and IAEA-N1, IAEA-N2 and USGS25 for N.

\section{RESULTS AND DISCUSSION Cansiliella servadeii behavior}

C. servadeii were associated with active moonmilk deposition at Site B (Figures 1 and 2A). Individuals were observed submerged in the percolating waters that flow over the moonmilk (up to 1 to $40 \mathrm{~mm}$ water depth) (Figure 2). C. servadeii occurred in densities of 2 to 10 specimens $/ \mathrm{m}^{2}$ (with a mean of 3.8 specimens / $\mathrm{m}^{2}$ on five different carbonate surfaces) (Figure 2B), and at least 20 specimens were observed partially to totally 
Maurizio G. Paoletti, Mattia Beggio, Angelo Leandro Dreon, Alberto Pamio, Tiziano Gomiero, Mauro Brilli, Luca Dorigo,
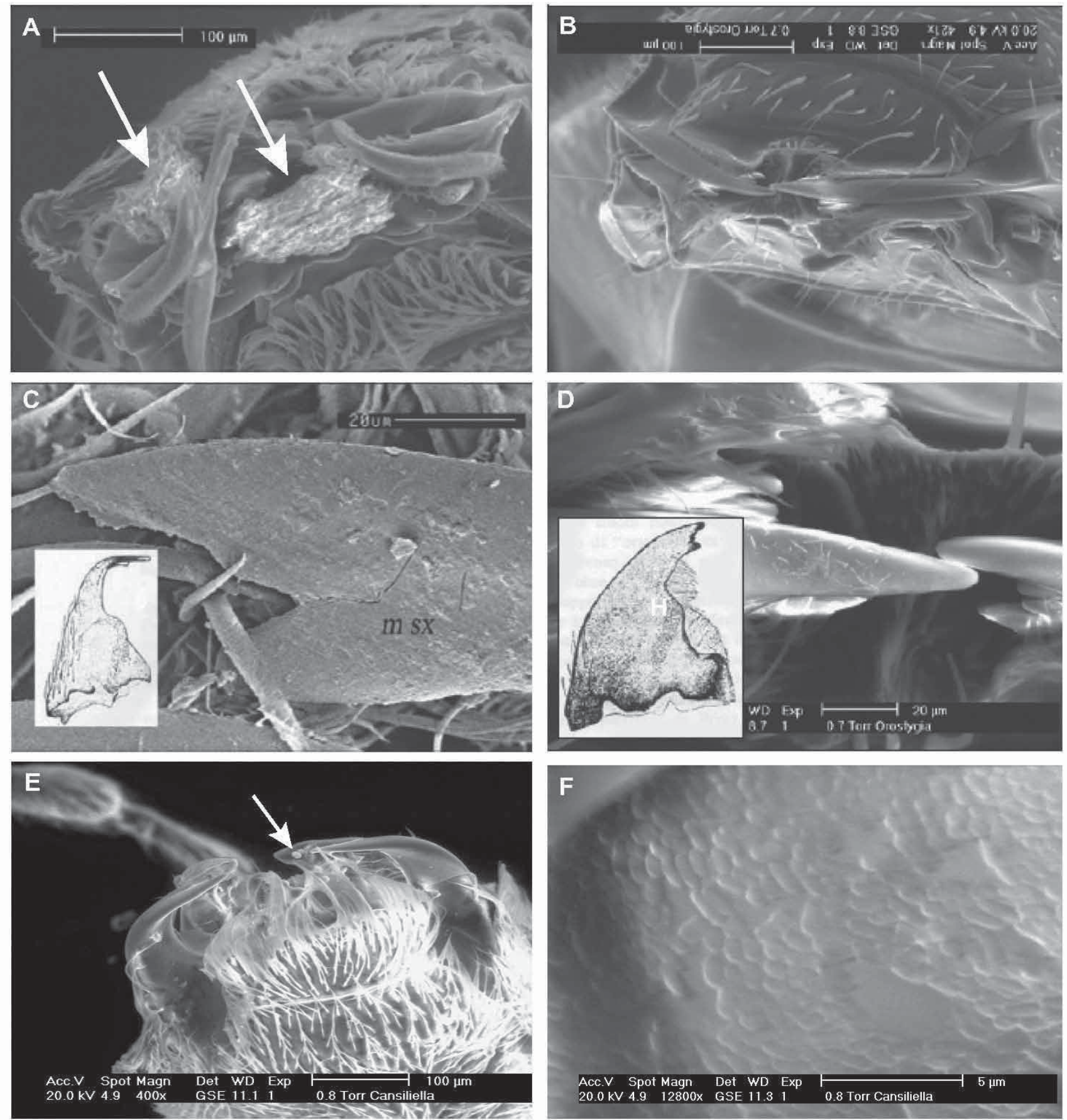

Fig. 3. Environmental scanning electron photomicrographs of Cansiliella servadeii and Orostygia pretneri mouth parts. (A) Frontal view of C. servadeii mouth with a piece of moonmilk in mouth (arrows). Scale bar is $100 \mu \mathrm{m}$. (B) Frontal view of O. pretneri head and mouth parts. Scale bar is $100 \mu \mathrm{m}$ (figure is intentionally turned upside down for comparison to panel A). (C) Left mandible ( $\mathrm{m} \mathrm{sx}$ ) of $C$. servadeii showing wear on the tip and edge. Inset drawing is of the whole mandible. Scale bar is $20 \mu \mathrm{m}$. (D) Left mandible of $O$. pretneri for comparison to $C$. servadeii mandible. Inset drawing is of the whole mandible. Scale bar is $20 \mu \mathrm{m}$. (E) C. servadeii mouth part showing microbial cells (arrow) on the top right mandible. Scale bar is $100 \mu \mathrm{m}$. (F) C. servadeii top left mandible with microbial cell layer on the galea. Scale bar is $5 \mu \mathrm{m}$.

submerged in the percolating waters between 4 to 20 $\mathrm{mm}$ depth (Figure 2C). Engaged mouthparts denote feeding behavior, and when seen associated with the moonmilk, C. servadeii stopped from time to time with the head prone and mouthparts engaged at the water-moonmilk interface (Figure 2 D, E). C. servadeii spends considerable time (about $49 \%$ ) preening its head, legs, and antennae; typically, this behavior is to move organic particles towards the mouth. Only on a few occasions were beetles found away from the percolating waters, and they moved much faster than in the percolating waters. We did not observe specimens inside stagnant water bodies within the cave or in stream passages. Additionally, beetles were not or rarely observed with engaged mouthparts (grazing or feeding) on the limestone host rock (Figure 2A). The movement and behavior can be readily observed from video (http://geol.1su.edu/aengel/publications.htm). 

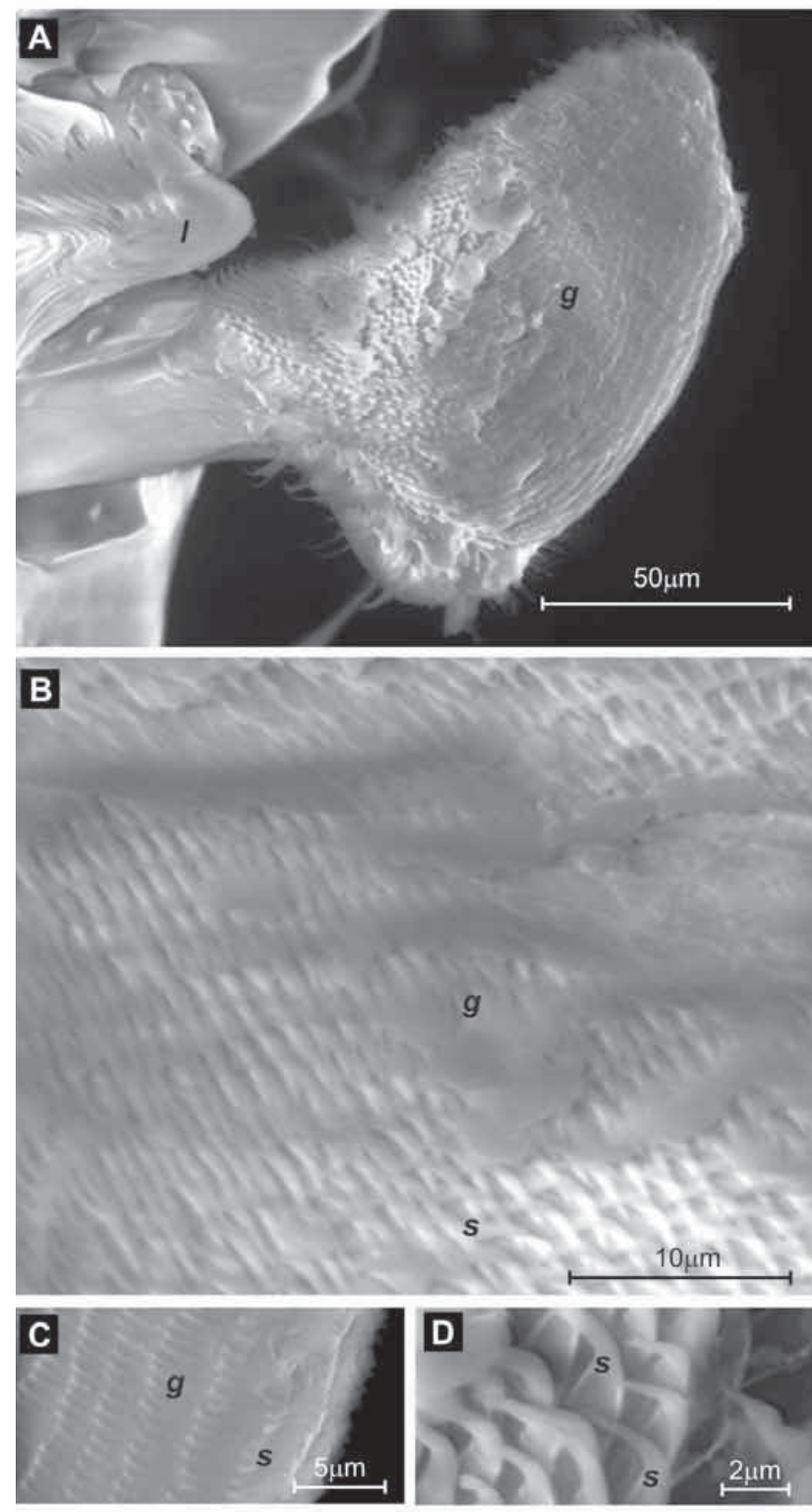

Fig. 4. Environmental scanning electron photomicrographs of Cansiliella servadeii galeas, A. upper side view of the spoon-shaped organ. B,C magnified surface showing racks with spines and $D$ further magnification of spines. $g$ = galea; $\mid$ = lacinia; $s=$ spines .

Observed semi-aquatic foraging was associated with active displacement of superficial sediment granules, resulting in disrupted moonmilk trenches 0.2-3 $\mathrm{mm}$ long. We considered that moving inside the percolating waters could cause stress to $C$. servadeii due to the sheering force of the moving water, as well as physiological stress from being submerged for long periods of time. Based on our observations, however, physiological stress may be reduced because the beetles adjust their body position in the water by elytral apical movements to form a bubble of air under the elytra and around the body (Figure 2E). This behavior, which is common among aquatic beetles (e.g., Hydrophilidae; Thorp \& Covich, 1991), likely aerates the top layers of the moonmilk in contact with percolating water.
Although $C$. servadeii mouthparts have been previously described (Paoletti, 1972, 1973,1980), we confirmed that the left and right mandibles are hoeshaped (Figure 3A and $\mathrm{C}$ ), and that the right branch had 4-5 short lobes and the left branch had two larger teeth. Carbonate particles up to $80 \mu \mathrm{m}$ wide were found inside $C$. servadeii mouths (Figure 3A), and the mouthpart structures were consistently worn and abraded compared to those of $O$. pretneri (Figure $3 \mathrm{C})$. Based on the behavior we observed, the most likely cause for abrasion would come from browsing relatively rigid substrate. The surfaces of $C$. servadeii galeae and mandibles had rod-shaped structures that we interpreted as adhered microbial cells (Figure 3D and E). From the size of the mouthparts, we estimated that it would be possible for $C$. servadeii to browse easily from $\sim 10$ to $60 \mu \mathrm{m}$ depths into the moonmilk (Figure 2D and Figure 3A), although larger particles were also seen in their mouths (Figure 3A). Galeae were covered by rows of spines that resemble a brush or rack (Fig. $4 \mathrm{~A}, \mathrm{~B}, \mathrm{C}$ ). The spines were $\sim 1-1.5 \mu \mathrm{m}$ apart, which was appropriate spacing for bacterial cells to collect (Figure 4 D).

\section{Physicochemistry of cave water and moonmilk}

The percolating waters within Grotta della Foos were $8.8^{\circ} \mathrm{C}$ at a pH of 8.25 , dissolved oxygen content of $10.8 \mathrm{mg} / \mathrm{L}$, and conductivity of $225 \mu \mathrm{S} / \mathrm{cm}$. Dissolved constituents were: $\mathrm{Na}^{+}, 0.2 \mathrm{mg} / \mathrm{L} ; \mathrm{K}^{+},<0.05 \mathrm{mg} / \mathrm{L}$; $\mathrm{NH}_{4}^{+}, 0.3 \mathrm{mg} / \mathrm{L} ; \mathrm{Ca}^{2+}, 45.2 \mathrm{mg} / \mathrm{L} ; \mathrm{Mg}^{2+},<0.05 \mathrm{mg} / \mathrm{L}$; $\mathrm{Cl}^{-}, 1.2 \mathrm{mg} / \mathrm{L} ; \mathrm{HCO}_{3}^{-}, 149.5 \mathrm{mg} / \mathrm{L} ; \mathrm{NO}_{2}^{-}, 0.3 \mathrm{mg} / \mathrm{L}$; $\mathrm{NO}_{3}{ }^{-}, 4.5 \mathrm{mg} / \mathrm{L} ; \mathrm{PO}_{4}{ }^{2-}, 0.2 \mathrm{mg} / \mathrm{L} ; \mathrm{SO}_{4}{ }^{2-}, 3.5 \mathrm{mg} / \mathrm{L}$. The dissolved organic carbon in the water had a mean value of $10.11 \mathrm{mg} / \mathrm{L}$. The elemental composition of the moonmilk (by \% weight) had 39\% Ca, 39\% O, 19\% $\mathrm{Al}, 15 \% \mathrm{C}, 3 \% \mathrm{Si}, 2 \% \mathrm{Fe}$, and $<1 \%$ each of $\mathrm{Mg}, \mathrm{P}, \mathrm{S}$, and $\mathrm{K}$. The organic $\mathrm{C}$ composition of the moonmilk was $0.06-0.52 \%$, with $0.01-0.05 \%$ organic $\mathrm{N}$. The bulk of the organic $\mathrm{C}$ was considered to be microbial biomass based on the lack of photosynthetically derived organic matter detected in the moonmilk (Beggio, 2009). With a $\mathrm{C} / \mathrm{N}$ ratio for the moonmilk of $\sim 9.4$, and $\sim 9.8$ for the water, both the moonmilk and water have high, nutritionally balanced content and can support high bacterial growth efficiency (Del Giorgio \& Cole 1998; Farjalla et al., 2009).

\section{Stable isotope analyses}

To examine the food web structure and trophic interactions occurring in Grotta della Foos for C. servadeii, we performed isotope ratio analyses to evaluate the status of the beetle in comparison with the habitat water, moonmilk, and other cave and surface animals (Figure 5). The $\delta^{13} \mathrm{C}$ value for water dissolved inorganic $\mathrm{C}$ was $-17.1 \%$, and the $\delta^{13} \mathrm{C}$ value for organic $\mathrm{C}$ in water was $-25.8 \%$. Moonmilk organic C averaged $-24.2 \%(n=10)$. The average $\delta^{13} \mathrm{C}$ value for C. servadeii bodies was $-20.7 \%$ o $(n=8)$. The separated gut contents $(\mathrm{n}=3)$ had consistent isotopic values to the full body for several beetles $(n=3)$, suggesting that the full body measurements also represented the food source. $C$. servadeii $\delta^{13} \mathrm{C}$ values were similar to those for $M$. lavalensis (unpaired t-test $P=0.17$ ), but 


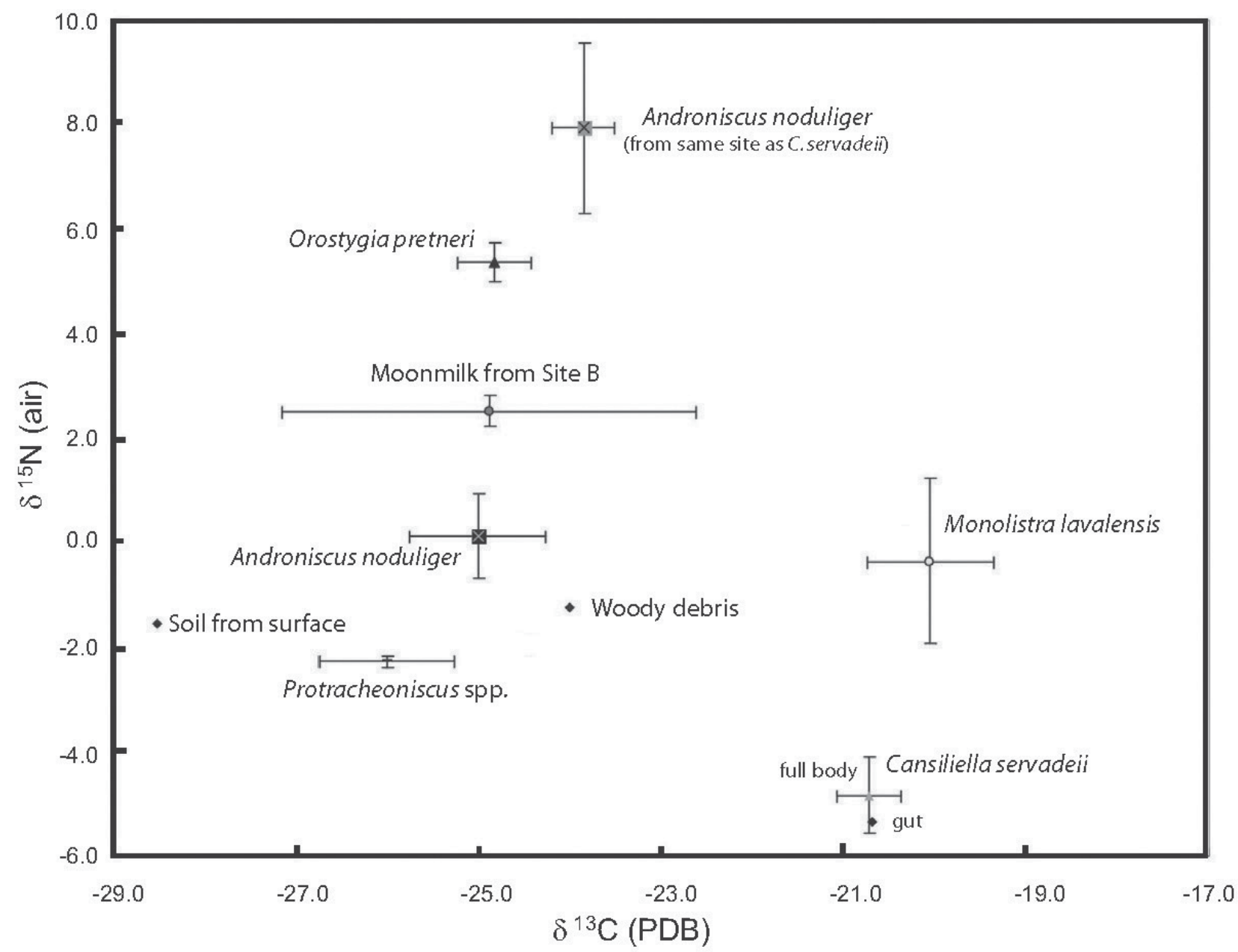

Fig. 5. Carbon and nitrogen stable isotope ratio analyses from individual animals, moonmilk, and soils (cross lines indicate mean and the $\pm 1 \mathrm{~s})$. Moonmilk $\left(\mathrm{n}={ }^{* *}\right.$ ), C. servadeii ( $n=8$ for whole bodies and $n=3$ for the gut and full body analyses), and A. noduliger $(n=2)$ were collected from Site B, shown on Fig. 1. O. pretneri was collected from Site $A(n=4)$. M. lavalensis was collected from Site $B(n=2)$. A. noduliger was collected from another area of the cave $(n=4)$, associated with woody debris $(n=4)$. Protracheoniscus spp. was outside the cave associated with soil $(n=3)$.

not to Site B A. noduliger and $A$. noduliger from Site $\mathrm{D}$, or other invertebrates from the cave (Figure 5 ). The distinct position of $C$. servadeii in $\mathrm{C}$ and $\mathrm{N}$ isotope space can be explained by the other dietary habitats of other cave invertebrates. For instance, A. noduliger is a terrestrial isopod, and like $O$. pretneri, consumes plant and especially animal-derived organic detritus.

Animals occupying higher trophic levels should have heavier isotopic compositions compared to their diet, especially with ascending trophic level structure. For the $\mathrm{C}$ isotope system, an enrichment of 0.5 to $3 \%$ is expected for a consumer relative to its diet (e.g., Post, 2002), being attributed to preferential loss of the lighter isotope during respiration by the consumer, preferential uptake of ${ }^{13} \mathrm{C}$ during digestion, or metabolic fractionation of tissue synthesis (e.g., lipids tend to have lighter composition compared to other tissues). The data would thus be compatible with $C$. servadeii obtaining its organic $\mathrm{C}$ either from the dissolved organic pool from the percolating water in the hygropetric habitat or from the moonmilk, as both have more negative $\delta^{13} \mathrm{C}$ compositions.

The $\mathrm{N}$ isotope values allow for the evaluation of possible food sources. The $\delta^{15} \mathrm{~N}$ values for the percolating waters, containing mainly inorganic nitrate, was $-10.9 \%$, with moonmilk having values around $+2 \%$ o. Sustained microbial growth likely causes the $\delta^{15} \mathrm{~N}$ values for the moonmilk to become positive if the microbial communities were utilizing organic $\mathrm{N}$ in the moonmilk, such as from beetle excrement (e.g., Macko \& Estrep, 1984; Hoch et al., 1992; Lehmann et al., 2002). The positive $\delta^{15} \mathrm{~N}$ composition of the moonmilk is likely due to increased microbial degradation of isotopically depleted organic matter that causes the nitrate pool to become increasingly more depleted. With ascending trophic level and limited microbial recycling of $\mathrm{N}$, the expected $\delta^{15} \mathrm{~N}$ values of animals should increase by at least 3\%o (Peterson \& Fry, 1987; Ponsard \& Arditi, 2000; Post, 2002), which is attributed to enrichment in tissue content relative to food source due to excretion of ${ }^{15} \mathrm{~N}$-depleted recalcitrant material (e.g., urea, ammonia). Because the body of $C$. servadeii had a mean $\delta^{15} \mathrm{~N}$ composition of $-4.8 \%$, our data appear to exclude the possibility that moonmilk is an exclusive source of food for $C$. servadeii, as the moonmilk $\delta^{15} \mathrm{~N}$ composition is more positive than the insect. The $\delta^{15} \mathrm{~N}$ composition of the percolating water, in which the beetle is constantly submerged, is a more probable candidate for the $\mathrm{N}$-based nutrition of $C$. servadeii. 


\section{Cansiliella food web interpretation}

In conclusion, although the specialized mouthparts for Cansiliella have been known for many years, little has been done to understand why Cansiliella is different than other troglobitic Leptodirinae (e.g., Paoletti, 1973,1980; Moldovan et al., 2004; Sket, 2004). The feeding behavior of $C$. servadeii, and direct manipulation and association with moonmilk in the Grotta della Foos habitat, suggest that the insect may make use of the moonmilk for its nutrition. However, the stable $\mathrm{C}$ and $\mathrm{N}$ isotope data provide some evidence against supporting this hypothesis, particularly with respect to the $\delta^{15} \mathrm{~N}$ composition of the beetles. Part of the inconsistent evidence is because of the unique microbial communities in the moonmilk, which are currently being described (Engel et al., unpublished data). Microbial recycling of isotopically variable $\mathrm{C}$ and $\mathrm{N}$ sources by those microbes, as well as the isotopic influence of living submerged in water with a unique isotope composition, may play a role in the C. servadeii isotopic compositions. Nevertheless, wherever $C$. servadeii is obtaining its organic $\mathrm{C}$ and $\mathrm{N}$ for its diet directly from the water, or from the moonmilk, or both, the constant browsing and squeezing of the moonmilk would cause the observed, abraded beetle mouthparts. Further work will help us to understand the microbial communities in the moonmilk associated with $C$. servadeii, and will uncover additional unique explanations for morphological adaptations of other troglobites in cave hygropetric habitats.

\section{ACKNOWLEDGEMENTS}

Speleological groups from Pradis, the Gruppo Speleologico Idrologico Friulano, Udine, and the Gruppo Speleologico of Pordenone helped on cave trips. Fieldwork, figure, manuscript, and photo suggestions were provided by M. Foissner, O. Coppellotti, V. Toniello, G. Concina, V. Simonutti, R. Mazzaro, M. Simonetti, R. Caicci, L. Salmaso, C. Fun lan, and R. Bertoni. The research and manuscript benefited from input by L. Deharveng, B. Jalzic, O. Moldovan, J. Mulec, M.L. Porter, U. Sauro, B. Sket, and two anonymous reviewers.

\section{REFERENCES}

Beggio M., 2009 - Nuova catena alimentare basata su batteri del moonmilk. University of Padova, thesis. Padova, Italy. 42 p.

Blyth A.J. \& Frisia S., 2008 - Molecular evidence for bacterial mediation of calcite formation in cold high altitude caves. Geomicrobiology Journal, 25: 101-111.

Borsato A., Frisia S., Jones B. \& van der Borg K., 2000 Calcite moonmilk: crystal morphology and environment of formation in caves in the Italian Alps. Journal of Sedimentary Research, 70: 1179-1190.

Cañaveras J.C., Cuezva S., Sanchez-Moral S., Lario J., Laiz L., Gonzalez J.M. \& Saiz-Jimenez C., 2006 - On the origin of fiber calcite crystals in moonmilk deposits. Naturwissenschaften, 93: 27-32.

Del Giorgio P.A. \& Cole J.J., 1998 - Bacterial growth efficiency in natural aquatic ecosystems. Annual Review of Ecology and Systematics, 29: 503-541

DeNiro M.J. \& Epstein S., 1981 - Influence of diet on the distribution of nitrogen isotopes in animals. Geochimica et Cosmochimica Acta, 45: 341-351.
Farjalla V. F., Marinho C.C., Faria B.M., Amado A.M., Esteves F. de A., Bozelli R.L. \& Giroldo D., 2009 Synergy of fresh and accumulated organic matter to bacterial growth. Microbial Ecology 57: 657-666

Gasparo F., 1971 - La grotta della Foos presso Campone (Prealpi Carniche). Mondo Sotterraneo, 1: 37-52.

Gerič B., Pipan T. \& Mulec J., 2004 - Diversity of culturable bacteria and meiofauna in the epikarst of Škocjanske jame caves (Slovenia). Acta Carsologica, 33: 301-309.

Giachino P.M. \& Vailati D., 2006 - Kircheria beroni, a new genus and new species of subterranean hygropetricolous Leptodirinae from Albania. Subterranean Biology, 4: 103-116.

Gibert J. \& Deharveng L., 2002 - Subterranean ecosystems: A truncated functional biodiversity. BioScience, 52: 473-481

Hill C.A. \& Forti P., 1997 - Cave Minerals of the World. Huntsville, Alabama: National Speleological Society, $446 \mathrm{p}$.

Hoch M.P., Fogel M.L. \& Kirchman, D.L., 1992 - Isotope fractionation associated with ammonium uptake by a marine bacterium. Limnology and Oceanography, 37: 1447-1459.

Jeannel R., 1924 - Monographie des Bathsyciinae. Arch. Zool. Exp. Gén., 63: 1-436.

Lehmann M.F., Bernasconi S.M., Barbieri A. \& McKenzie J.A., 2002 - Preservation of organic matter and alteration of its carbon and nitrogen isotope composition during simulated and in situ early sedimentary diagenesis. Geochimica et Cosmochimica Acta, 66: 3373-3584.

Macko S.A. \& Estrep M.L.F., 1984 - Microbial alteration of stable nitrogen and carbon isotopic compositions of organic matter. Organic Geochemistry, 6: 787-790.

Midwood A.J. \& Boutton T.W., 1997 - Soil carbonate decomposition by acid has little effect on $\delta^{13} \mathrm{C}$ of organic matter. Soil Biology and Biochemistry, 30: 1301-1307.

Moldovan O.T., Jalzic B. \& Erichsen E., 2004 Adaptation of the mouthparts in some subterranean Cholevinae (Coleoptera, Leiodidae). Nat. Coroat., 13: $1-18$.

Mulec J., Zalar P., Zupan-Hajna N. \& Rupnik M., 2002 - Screening for culturable microorganisms from cave environments (Slovenia). Acta Carsologica, 31: 177-187.

Northup D.E., Dahm C.N., Melim L.A., Crossey L.J., Lavoie K.H., Mallory L., Boston P.J., Cunningham, K.I. \& Barn S.M., 2000 - Evidence for geomicrobiological interactions in Guadalupe caves. Journal of Cave and Karst Studies, 62: 80-90.

Northup D.E. \& Lavoie K., 2001 - Geomicrobiology of caves: a review. Geomicrobiology Journal, 18: 199222.

Opsahl S.P. \& Chanton J.P., 2006 - Isotopic evidence for methane-based chemosynthesis in the Upper Floridan aquifer food web. Oecologia, 150: 89-96.

Paoletti M.G., 1972. Un nuovo Catopide pholeuonoide del Cansiglio (Prealpi Carniche). Boll. Mus. Civ. St. Nat. Venezia, 22-23: 119-131.

Paoletti M.G., 1973 - Notizie sistematiche ed ecologiche su di un nuovo interessante genere del Cansiglio Cansiliella: Suppl. Boll. Mus. Civ.S. Nat. Venezia, 24: 81-88. 
Paoletti M.G., 1980 Dati aggiuntivi alla conoscenza del genere Cansiliella Paoletti (Col. Bathysciinae). Redia, Firenze, 63: 67-80.

Paoletti M.G., Beggio M., Pamio A., Gomiero T., Brilli M., Dreon A.L., Toniello V. \& Engel A.S., 2009 - Comparison of three moonmilk cave habitats associated with troglobitic beetles. In: White W.B. (Ed.), Proceedings 15th International Congress of Speleology: Kerrville, Texas, 1: 400-403.

Perreau M. \& D. Pavicevic 2008. The genus Hadesia Mueller, 1911 and the Phylogeny of Anthroherponina (Coleoptera, Leiodidae, Cholevinae, Leptodirini). In: D.Pavicevic \& M. Perreau (eds) Advances in the studies of the fauna of the Balkan peninsula. Papers dedicated to the memory of Guido Novellier. p 215-219.

Peterson B.J. \& Fry B., 1987 - Stable isotopes in ecosystem studies. Annual Review of Ecology and Systematics, 18: 293-320.

Piva E., 2000 - Contributo alla conoscenza del genere Cansiliella, con descrizione di una nuova specie (Coleoptera Cholevidae). Boll. Soc. Entomol. Ital., 132: 123-134.

Ponsard S. \& Arditi R., 2000 - What can stable isotopes $\left(\delta^{15} \mathrm{~N}\right.$ and $\left.\delta^{13} \mathrm{C}\right)$ tell about the food web of soil macroinvertebrates? Ecology, 81: 852-864.
Post D.M., 2002 - Using stable isotopes to estimate trophic position: models, methods, and assumptions. Ecology, 83: $703-718$.

Remy P., 1940 - Sur le mode de vie des Hadesia dans la grotte Vjetrenica. Rev. Franc. Entomol., 7: 1-8.

Simon K., Benfield E.F. \& Macko S.A., 2003 - Food web structure and the role of epilithic biofilms in cave streams. Ecology, 84: 2395-2406.

Sket B., 2004 - The cave hygropetric - a little known habitat and its inhabitants. Arch. Hydrobiol., 160: 413-425.

Thorp J.H. \& Covich A.P., 1991 - Ecology and Classification of North American Freshwater Invertebrates. Academic Press, Inc. San Diego, CA, $927 \mathrm{p}$.

Van de Kamp J.L., Nichols D.S. \& Sandserson K., 2004 - The microbe-mineral interface in caves: a moonmilk perspective. Geological Society of America Abstracts with Programs, 36: 257.

West J.B., Bowen G.J., Cerling T.E. \& Ehleringer J.R., 2006 - Stable isotopes as one of nature's ecological recorders. Trends in Ecology \& Evolution, 21: 408-414. 